\title{
Animal Food Demand in Indonesia: A Quadratic Almost Ideal Demand System Approach
}

\author{
Nikmatul Khoiriyah', Ratya Anindita², Nuhfil Hanani², Abdul Wahib Muhaimin ${ }^{2}$ \\ ${ }^{1}$ Deparment of Agribusiness, Faculty of Agriculture, University of Islam Malang, Indonesia \\ ${ }^{2}$ Deparment of Socio Economic, Faculty of Agriculture, Brawijaya University, Malang, Indonesia
}

\begin{abstract}
This research aims to analyze the impact of the price change, the income, and the household size on the demand for five commodity groups, i.e. eggs, chicken, beef, fish and powder milk. The data utilized in this study is based on the Indonesian National Socio-Economic Survey 2016. There are 291,414 data of households in Indonesia which was analyzed by Quadratic Almost Ideal Demand System. The result shows that all of the price elasticity was negative and the income elasticity was positive. The effect of income causes the demand for animal foods in Indonesia to be more elastic rather than other commodities with the highest demand of elasticity, i.e. beef, powder milk, fish, meat and eggs by $2.19 \%, 1.96 \%, 1.53 \%$, $1.43 \%$, and $0.53 \%$ respectively. The beef has the most sensitive effect to changes the income. Therefore, the government requires maintaining the stability of beef prices to increase beef consumption in Indonesia
\end{abstract}

\section{Keywords}

Food demand system, elasticity, price change, Indonesia.

Khoiriyah, N., Anindita, R., Hanani, N. and Muhaimin, A. W. (2019) "Animal Food Demand in Indonesia: A Quadratic Almost Ideal Demand System Approach", AGRIS on-line Papers in Economics and Informatics, Vol. 12, No. 2, pp. 85-97. ISSN 1804-1930. DOI 10.7160/aol.2020.120208.

\section{Introduction}

Worldwide and Indonesia currently deal with the significant fundamental change. McKinsey Global Institute in 2012 reveals that Indonesia's fast-growing economy reaches the sixteenth biggest in the world. There are 45 million Indonesian people that are included in a consumptive cluster. There are $53 \%$ of residents in Indonesia living in urban lifestyle. In addition, there are 55 million skilled workers in business economics. Also, there is $\$ 0.5$ trillion market opportunities in some fields such as in consumer services, agriculture, fisheries, resources, and education. One of the consumptive class expenditure and urban lifestyles is the share of expenditure after the staple food, i.e. the animal foods (Fabiosa, 2005). It is important to consume animal foods because it contains beneficial nutrient for the body. Also, it should be consumed by the community (Akaichi and Revoredo-Giha, 2014). Animal foods such as eggs, chicken, beef, fish, and milk contain all types of essential amino acid which cannot automatically be produced by the human body (Legendre et al., 2008). Therefore, nutrients fulfillment depends on consuming food and beverage. Most countries in the world classify animal foods as luxury commodities (Vu and Glewwe, 2011; Elijah Obayelu et. al., 2009; Uregia et al., 2012). It is expensive and has a fluctuated demand (Sacli and Ozer, 2017).The impact of protein deficiency can worsen for people, more specifically for babies. The protein deficiency suffered by babies can affect permanently and can have a long-term impact, as well as cannot be recovered (Cupák at al., 2015).

The increasing price of animal foods can cause the decreasing capability to purchase animal foods. Also, the declining real income can trigger the declining of animal foods consumption. In this case, the households may have a deficiency of protein from animal foods. There are only 3\% of households in Indonesia consuming beef (Statistik, 2015). However, align with the increasing income and public awareness of nutrition and food quality, the pattern of eating consumption has changed to consume animal foods (Baharumshah and Mohamed, 1993). The growth of income will shift the consumption of high-carbohydrate staple foods to prefer the more expensive food such as meat and milk (Fabiosa, 2005). The projection of changes in the daily calories consumed 
by the Indonesian people in 2030 will increase quite high. More specifically, the commodity of all types of meat will increase by $90 \%$. In contrast, the daily consumption of rice will decrease by $4 \%$ (Krisnamurthi, 2016). The increasing consumption of all types of meat will enhance the high demand for meat. Further, animal foods price tend to rise in the last ten years which is illustrated in Figure 1. The growth of incremental pricing average of eggs annually is $10.94 \%$. Then, the annual pricing of the other animal foods such as milk, beef, chicken increments respectively by $6.94 \% ; 9.58 \% ; 5.24 \%$ (Statistik, 2015). Fulfillment of animal foods declined dramatically in 2013. Then, they increased again in 2014. While Indonesia's protein consumption was recorded at 55.01 grams/ capita/ year in 2010. In 2014, it was annually recorded as 53.91 grams/ capita (Statistik, 2015). This value was below The Standard National Protein Adequacy Rate, i.e. 57 grams of protein/capita per day. Also, it became the lowest rate in ASEAN (Fabiosa, 2005). Therefore, it is pivotal to investigate how does the effect of the price and income on the demand for animal food.

Many previous studies investigate the system of food demand in emerging economies and advanced economies. Some approaches that were utilized such as LES (Linear Expenditure System), Rotterdam model, Translog Model, and AIDS (Almost Ideal Demand System). In addition, the most popular approach is QUAIDS (Quadratic AIDS). The implementation of AIDS can be shown in the research of demand food system (Deaton, 1990). Then, (Pangaribowo and Tsegai, 2011) studied the demand food system by using a QUAIDS. However, the study of animal food was still under search. Therefore, by using a QUAIDS, this research aims to identify in detail how does the effect of income, price, and the demographic factors on the demand for animal food. Also, this research investigates deeply the income elasticity and price elasticity on animal food. Moreover, this research shed lights on how does the nature between substitute and complementary within animal food. Therefore, the objective of this research is to analyze the demand for animal food by using a QUAIDS model approach. Through this research, it will be obtained how the vulnerability and flexibility of each group of urban and rural households on the impact of price changes based on the dynamics of food demand for animal sources of protein by considering the factors of preference, substitution, complementation. This research will recommend the government to arrange the scenario of requisite policy to protect farmers, Indonesian people and related industry. The contribution of this research can be the guidance for the Indonesian government to manage the dynamics of animal product trading systems more precisely and measurably. Therefore, the role of government can be more accountable as the decision maker. More specifically, it can be more important in determining the best alternative policy for the benefit of industrial and farm development. For example, the result of this research can maximize the protective role for the farmers and the community regarding the consumption of animal food. It can stimulate the achievement of protein standard which is $57 \mathrm{gram} /$ capita a day per households in Indonesia.

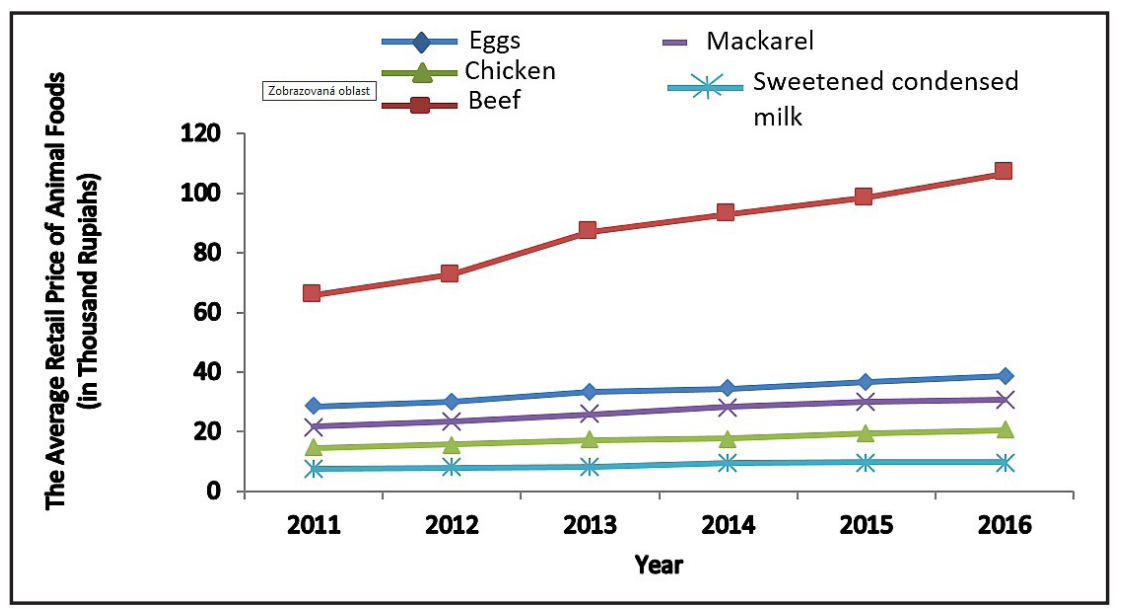

Source :Modified and adapted from (Agustina, 2016; Hanny P. Muliany, 2016; Roch Widaningsih, 2016; Suryani, 2016)

Figure 1: The Development of Average Retail Prices of Animal Food Protein. 


\section{Materials and methods}

\section{Data and descriptive statistics}

This research used the secondary data from Susenas (Survei Sosial Ekonomi Nasional) in March 2016 which comprises thirty-four province data. The data analyzed were the consumption of animal foods data and the household expenditure on animal foods, i.e. eggs, chicken, beef, fish and powder milk. In addition, sociodemographic data (households' residence status (rural/urban)), data on the number of households' members, and households' income data were required. Then, data were analyzed by STATA 14 . The number of samples is 291,414 households from the rural and urban area.

\section{The food group expenditures in households}

There are two assumptions utilized regarding the expenditure source in households. Firstly, this research used total households' expenditure for five categories of comestibles such as staple food, grain food, animal foods, fruits and vegetables and supplementary food. Secondly, we employed the total expenditures for animal foods allocated to five food groups, i.e. eggs, beef, chicken, fish and powder milk which are shown in the following Table 1.

\begin{tabular}{|c|c|c|}
\hline Group & Group name & Goods/items \\
\hline 1 & Eggs & $\begin{array}{l}\text { Chicken eggs, free-range chicken } \\
\text { eggs, duck eggs }\end{array}$ \\
\hline 2 & Chicken & $\begin{array}{l}\text { Broiler chicken meat, free-range } \\
\text { chicken meat }\end{array}$ \\
\hline 3 & Beef & Beef \\
\hline 4 & Fish & Fish, shrimp, squid and shellfish \\
\hline 5 & Milk powder & $\begin{array}{l}\text { Infant milk powder, formula milk } \\
\text { powder }\end{array}$ \\
\hline
\end{tabular}

Source: Modified from the National Bureau of Statistics classifications (Statistik, 2015)

Tabel 1: The items of the commodity animal foods groups.

The percentage share of food group expenditures on total food based on 2016 quantiles are shown in Table 2. The lowest quantile (Q1) of the households' group shares has the highest percentage which is the grains by $29.65 \%$. This is in line with the research of (Tefera, et al., 2014) Grains become the highest demand for food commodity compared to the others. It also becomes the highest percentage among the other quantiles. However, the trend of grains declines within the next quartiles. The trend of grains deteriorates by $22.13 \%$. In contrast, the trend of meat, as well as and eggs and milk expenditure increased respectively by $4.21 \%$ and $3.15 \%$. According to (Alem, 2011; Attanasio et. al., 2013; Vu and Glewwe, 2011), the percentage of the group of protein foods such as egg and powder milk, meat

\begin{tabular}{|c|c|c|c|c|c|c|c|c|}
\hline \multirow[t]{2}{*}{ Food Group } & \multicolumn{8}{|c|}{ Food group expenditure (\%) } \\
\hline & $\begin{array}{c}\text { Q1 } \\
\text { (low) }\end{array}$ & Q2 & Q3 & Q4 & $\begin{array}{c}\text { Q5 } \\
\text { (high) }\end{array}$ & Total & Trend & Trend Value \\
\hline Grains & 29.65 & 22.99 & 17.88 & 13.36 & 7.51 & 14.02 & $\downarrow \downarrow$ & -22.13 \\
\hline Meat & 1.97 & 2.68 & 3.41 & 4.36 & 6.18 & 4.46 & $\wedge$ & 4.21 \\
\hline Eggs and milk & 4.19 & 4.80 & 5.32 & 6.05 & 7.34 & 6.08 & $\wedge$ & 3.15 \\
\hline Vegetables & 9.08 & 8.70 & 8.31 & 7.75 & 6.16 & 7.49 & $\downarrow$ & -2.92 \\
\hline Drink material & 4.64 & 4.16 & 3.89 & 3.53 & 2.75 & 3.48 & $\downarrow$ & -1.89 \\
\hline Spices & 2.48 & 2.33 & 2.23 & 2.04 & 1.62 & 1.99 & $\downarrow$ & -0.86 \\
\hline Other consumption (noodle) & 2.28 & 2.27 & 2.24 & 2.15 & 1.77 & 2.05 & $\downarrow$ & -0.51 \\
\hline Finished food and Beverage & 19.32 & 22.68 & 24.32 & 27.83 & 36.47 & 29.05 & $\wedge \wedge$ & 17.15 \\
\hline Cigarette & 12.94 & 15.16 & 16.11 & 15.12 & 11.60 & 13.80 & & \\
\hline
\end{tabular}

Source: own processing 
and fish is enhancing along with the increasing income. This is in line with the research of McKinsey Institute (2012) that the consumption food in Indonesia has been shifted from the low carbohydrate to the high protein. Therefore, the price and income can be the determinant of the amount of animal foods consumption by households in Indonesia.

\section{The model estimation by Quadratic Almost Ideal} Demand System (QUAIDS)

This research employs QUAIDS to identify in detail about how does the effect of income, price, and the demographic factors on the demand for animal foods. More specifically, this study investigates the price elasticity and the income. Based on the non-parametric analysis of consumer purchasing patterns, the Engel curve requires a higher order than the logarithm of expenditure. QUAIDS is the development of the AIDS model with a quadratic logarithm. According to (Banks at al., 1997), this model is implemented to catch the curvature of the Engel curve by using the households' expenses survey. In this case, QUAIDS is the development AIDS model and it fulfils the characteristics of the demand function.

The Quadratic Almost Ideal Demand System (QUAIDS), developed by Banks, Blundell, and Lewbel (1997), which was further augmented with demographic variables by Poi (2013), is used to estimate price and food expenditure elasticities in the second stage. QUAIDS has been widely applied in the literature on food demand analysis. The QUAIDS augmented with demographic and other controls will use to examine the household food demand patterns, and thus availability and access to animal source foods, across region types (urban/rural).

QUAIDS model has features which are almost similar to the AIDS model. It can catch the curvature of the Engel curve. Therefore, QUAIDS is selected as the demand model to manage the empirical estimation strategy. In addition, this research expands the QUAIDS model with sociodemographic variables to comprehend the role of non-economic variables in the demand behavior of animal foods. The implementation of QUAIDS in emerging economies is still limited (Poi, 2012). The model of QUAIDS demand for animal foods in Indonesia can be shown in the following equation.

$w_{i}=\alpha_{i}+\sum_{j=1}^{n} \gamma_{i j} \ln \left(p_{j}\right)+\beta_{i} \ln \left(\frac{x}{a(p)}\right)+\frac{\lambda_{i}}{b(p)}\left(\ln \left(\frac{m}{a(p)}\right)\right)^{2}$

$$
\begin{aligned}
& \begin{array}{l}
w_{i}=\alpha_{i}+\sum_{j=1}^{k} \gamma_{i j} \ln p_{j}+\left(\beta_{i}+\boldsymbol{\eta}_{i}^{\prime} \mathbf{z}\right) \ln \left\{\frac{m}{\bar{m}_{0}(\mathbf{z}) a(\mathbf{p})}\right\} \\
+\frac{\lambda_{i}}{b(\mathbf{p}) c(\mathbf{p}, \mathbf{z})}\left[\ln \left\{\frac{m}{\bar{m}_{0}(\mathbf{z}) a(\mathbf{p})}\right\}\right]^{2}
\end{array} \\
& \text { where } c(\mathbf{p}, \mathbf{z})=\prod_{j=1}^{k} p_{j}^{\boldsymbol{\eta}_{j}^{\prime} \mathbf{z}}
\end{aligned}
$$

$w_{i}$ is the share expenses of eggs, chicken, beef, fish, and milk on the total expenses. $m$ is the total expenses for animal foods. Meanwhile, $a(p)$ and $b(p)$ are the prices of animal foods which are illustrated in the following equation.

$$
\begin{aligned}
& \ln \alpha(p)=\alpha_{0}+\sum_{k} \alpha_{k} \ln \left(p_{k}\right)+\frac{1}{2} \sum_{k} \sum_{l} \gamma_{k i} \ln \left(P_{k}\right) \ln \left(P_{1}\right) \\
& b(p)=\prod_{i-1}^{n} P_{i}^{\beta_{i}}
\end{aligned}
$$

Not only the AIDS model requires the restriction, the QUAIDS model also need it to maintain the consistency by utilizing the utility maximization. The equation is shown as follow.

$$
\text { Adding-up: } \begin{aligned}
\sum_{i=1}^{n} \alpha_{i} & =1 ; \sum_{i=1}^{n} \beta_{i}=0 ; \sum_{i=1}^{n} \gamma_{i j} \\
& =0 \forall j ; \sum_{i=1}^{n} \lambda_{i}=0
\end{aligned}
$$

Homogeneity: $\sum_{j=1}^{n} \gamma_{i j}=0 \forall i$, and

Symmetry: $\gamma_{i j}=\gamma_{j i} \gamma_{i j}=\gamma_{j i}$

Based on the previous model, the price elasticity is:

$\eta_{i j}=\frac{\mu_{i j}}{W_{i}}-\delta_{i j}$

In addition, the income elasticity is:

$\eta_{i}=\frac{\mu_{i}}{W_{i}}+1$

Where $\delta_{i j}$ is the delta Kronecker, $\mu_{i j}$ and $\mu_{i}$ are:

$$
\begin{aligned}
& \mu_{i j}=\frac{\partial W_{i}}{\partial \ln p_{j}}=\gamma_{i j}-\mu_{i}\left(\alpha_{j}+\sum_{k=1}^{n} \gamma_{j k} \ln p_{k}\right) \\
& -\frac{\lambda_{i} \beta_{j}}{b(p)}\left\{\ln \left(\frac{x}{a(p)}\right)^{2}\right\} \\
& \ln V=\left\{\left[\frac{\ln x-\ln a(p)}{b(p)}\right]^{-1}+\lambda(p)\right\}^{-1} \\
& \mu_{i j}=\frac{\partial W_{i}}{\partial_{x}}=\beta_{i}+\frac{2 \lambda_{i}}{b(p)}\left\{\ln \left(\frac{x}{a(p)}\right)\right\} \\
& \lambda(p)=\sum_{i=1}^{n} \lambda_{i} \ln p_{i} \\
& \alpha_{i}=\alpha_{0 i}+\sum_{m=1}^{M} \alpha_{m i} Z_{m} \\
& \sum_{i=1}^{n} \alpha_{0 i}=1 ; \sum_{i=1}^{n} \alpha_{m i}=0, \forall_{m} .
\end{aligned}
$$


Elasticity price model that was developed by Banks, Blundell and Lewbel (1997) is illustrated by the following equation:

$$
\begin{gathered}
w_{i}=\alpha_{i}+\sum_{j=1}^{\mathrm{k}} \lambda_{j} \ln p_{j}+\left[\frac{m}{\bar{m}_{0}(z) \alpha(p)}\right] \\
+\frac{\lambda_{i}}{b(\mathrm{p}) c(\mathrm{p}, z)}\left\{\ln \left[\frac{m}{\bar{m}_{0}(z) a(\mathrm{p})}\right]\right\}^{2}+\varepsilon \\
c(\mathbf{p}, \mathbf{z})=\prod_{j=1}^{k} p_{j}^{\eta_{j}^{\prime} z}
\end{gathered}
$$

The parameters generated from the QUAIDS model are used to calculate the own-price elasticity of both Hicksian and Marshallian, expenditure elasticity and cross price elasticity.

Marshallian price elasticity (Uncompensated) is:

$$
\begin{aligned}
\epsilon_{i j}^{u} & =-\delta_{i j}+\frac{1}{w_{i}}\left(\gamma_{i j}-\left[\beta_{i}+\eta_{j}^{\prime} z\right.\right. \\
& \left.+\frac{2 \lambda_{i}}{b(\mathbf{p}) c(\mathbf{p}, \mathbf{z})} \ln \left\{\frac{m}{a(\mathbf{p}) \bar{m}_{0}(\mathbf{z})}\right\}\right] \times\left(\alpha_{j}+\sum_{l} \gamma_{j l} \ln p_{l}\right) \\
& \left.-\frac{\left(\beta_{i}+\eta_{j}^{\prime} z\right) \lambda_{i}}{b(\mathbf{p}) c(\mathbf{p}, \mathbf{z})}\left[\ln \left\{\frac{m}{a(\mathbf{p}) \bar{m}_{0}(\mathbf{z})}\right\}\right]^{2}\right)
\end{aligned}
$$

Expenditure elasticity is:

$\mu_{i}=1+\frac{1}{w_{i}}\left[\beta_{i}+\eta_{j}^{\prime} z+\frac{2 \lambda_{i}}{b(\mathbf{p}) c(\mathbf{p}, \mathbf{z})} \ln \left\{\frac{m}{a(\mathbf{p}) \bar{m}_{0}(\mathbf{z})}\right\}\right]$

Hicksian elasticity (Compensated) is:

$\epsilon_{i j}^{c}=\epsilon_{i j}^{u}+w_{j} \mu_{i}$
Equation (1) to (15) adopted from Deaton and Muellbauer (1980), equation (16) to (20) adopted from (Poi, 2012) with reference to Banks et al. (1997).

\section{Results and discussion}

\section{The estimation of parameter}

The result of QUAIDS yields the parameter. This parameter presents the respond of households on the change of price, income, and the demographic variable of the number of household members. The parameter can analyze the elasticity of income elasticity, price, and cross price. All parameters have a significant error from $1 \%$ to $5 \%$. The parameter of income squares for all animal foods groups is significant. It indicates that there is a nonlinear relationship between total expenditure and animal foods demand. This result aligns with the previous study such as in Indonesia (Bopape and Myers, 2007; Pangaribowo and Tsegai, 2011), and in Ethiopia (Tefera et al., 2018). The quadratic parameters of expenditure on chicken and fish are negative. It indicates that chicken and fish are a normal item. On the other hand, the parameters of eggs, beef and milk are positive. It means that

\begin{tabular}{|c|c|c|c|c|c|}
\hline Parameter (Coefficient and SEM & Eggs (1) & Chicken (2) & Beef (3) & Fish (4) & Milk Powder (5) \\
\hline$\alpha$ & $0.199 * *$ & $-0.637 * *$ & $0.499 * *$ & $0.090^{* *}$ & $0.847 * *$ \\
\hline \multicolumn{6}{|l|}{ Income } \\
\hline$\beta$ & $0.008 * *$ & $-0.264 * *$ & $0.098 * *$ & $-0.001^{* *}$ & $0.158 * *$ \\
\hline$\gamma_{-} 1$ & $0.429 * *$ & $-0.148 * *$ & $-0.058 * *$ & $-0.039 * *$ & $-0.183 * *$ \\
\hline$\gamma_{-} 2$ & $-0.148 * *$ & $0.305 * *$ & $-0.097 * *$ & $0.046^{* *}$ & $-0.106 * *$ \\
\hline$\gamma_{-} 3$ & $-0.058 * *$ & $-0.097 * *$ & $0.026^{* *}$ & $0.022 * *$ & $0.107 * *$ \\
\hline$\gamma_{-} 4$ & $-0.039 * *$ & $0.046 * *$ & $0.022 * *$ & $-0.052 * *$ & $0.023 * *$ \\
\hline \multicolumn{6}{|l|}{ Income square } \\
\hline \multicolumn{6}{|l|}{ Demography } \\
\hline$\eta \_$hhm_tot & $-0.003 * *$ & $0.003 * *$ & $0.0001 * *$ & $0.0003 * *$ & $-0.0004 * *$ \\
\hline \multicolumn{6}{|l|}{ Demography } \\
\hline$\rho \_$hhm_tot & $0.009 * *$ & $0.009 * *$ & $0.009 * *$ & $0.009 * *$ & $0.009 * *$ \\
\hline
\end{tabular}
the commodity is a luxury item. Further, the parameters for estimating QUAIDS of animal foods consumed by household in Indonesia (all-HH/all household) both in rural and urban areas can be seen in Table 3, 4 and 5 .

Note: $* *$ and $*$ indicate significant at the $1 \%$ and $5 \%$ significance level, respectively

Source: research findings

Table 3: QUAIDS Parameter Estimates for all Indonesian household (all-HH) $(\mathrm{N}=291,414)$. 


\begin{tabular}{|c|c|c|c|c|c|}
\hline Parameter (Coefficient and SEM & Eggs (1) & Chicken (2) & Beef (3) & Fish (4) & Milk Powder (5) \\
\hline Constant & $-0.048 * *$ & $0.185^{* *}$ & $0.354 * *$ & $-0.184 * *$ & $0.693 * *$ \\
\hline \multicolumn{6}{|l|}{$\alpha$} \\
\hline Income & $-0.104 * *$ & $-0.056^{* *}$ & $0.092 * *$ & $-0.094 * *$ & $0.161 * *$ \\
\hline \multicolumn{6}{|l|}{$\beta$} \\
\hline Price & $0.584 * *$ & $-0.254 * *$ & $-0.105 * *$ & $0.037 * *$ & $-0.262 * *$ \\
\hline$\gamma_{-} 1$ & $-0.254 * *$ & $0.076^{* *}$ & $0.006 * *$ & $0.083 * *$ & $0.089 * *$ \\
\hline$\gamma \_2$ & $-0.105^{* *}$ & $0.006 * *$ & $0.040 * *$ & $-0.049 * *$ & $0.107 * *$ \\
\hline$\gamma \_3$ & $0.037 * *$ & $0.083 * *$ & $-0.049 * *$ & $0.021 * *$ & $-0.092 * *$ \\
\hline$\gamma_{-} 4$ & $-0.262 * *$ & $0.089 * *$ & $0.107 * *$ & $-0.092 * *$ & $0.158^{* *}$ \\
\hline \multicolumn{6}{|l|}{$\gamma_{-} 5$} \\
\hline Income square & $0.011 * *$ & $-0.013 * *$ & $0.005 * *$ & $-0.007 * *$ & $0.005 * *$ \\
\hline \multicolumn{6}{|l|}{$\gamma$} \\
\hline Demography & $-0.003 * *$ & $0.003 * *$ & $-0.0001 * *$ & $0.001 * *$ & $-0.0005^{* *}$ \\
\hline \multicolumn{6}{|l|}{$\eta \_$hhm_tot } \\
\hline Demography & $-0.043 * *$ & $-0.043 * *$ & $-0.043 * *$ & $-0.043 * *$ & $-0.043 * *$ \\
\hline$\rho \_$hhm_tot & & & & & \\
\hline
\end{tabular}

Note: ** and * indicate significant at the $1 \%$ and $5 \%$ significance level, respectively Source: research findings

Table 4: QUAIDS Parameter Estimates for Indonesian rural $(\mathrm{N}=155,438)$.

\begin{tabular}{|c|c|c|c|c|c|}
\hline Parameter (Coefficient and SEM & Eggs (1) & Chicken (2) & Beef (3) & Fish (4) & Milk Powder (5) \\
\hline Constant & $1.143^{*}$ & & & & \\
\hline$\alpha$ & & $-2.312 *$ & $0.871 * *$ & $0.228 * *$ & $1.070^{* *}$ \\
\hline Income & $0.132 * *$ & & & & \\
\hline$\beta$ & & $-0.474 * *$ & $0.141 * *$ & $0.034 * *$ & $0.168 * *$ \\
\hline Price & $0.418^{* *}$ & & & & \\
\hline$\gamma_{-} 1$ & $-0.415^{* *}$ & $-0.415 * *$ & $0.045 * *$ & $-0.016^{* *}$ & $-0.032 * *$ \\
\hline$\gamma \_2$ & $0.045^{* *}$ & $1.052 * *$ & $-0.293 * *$ & $-0.029 * *$ & $-0.315 * *$ \\
\hline$\gamma \_3$ & $-0.016^{* *}$ & $-0.293 * *$ & $0.055^{* *}$ & $0.054 * *$ & $0.139 * *$ \\
\hline$\gamma_{-} 4$ & $-0.032 * *$ & $-0.029 * *$ & $0.053 * *$ & $-0.067 * *$ & $0.058 * *$ \\
\hline$\gamma_{-} 5$ & & $-0.316^{* *}$ & $0.139 * *$ & $0.058^{* *}$ & $0.149 * *$ \\
\hline Income square & $0.018^{* *}$ & & & & \\
\hline$\gamma$ & & $-0.026^{* *}$ & $0.005^{* *}$ & $0.0002 * *$ & $0.003 * *$ \\
\hline Demography & $0.0007 * *$ & & & & \\
\hline$\eta \_$hhm_tot & & $-0.0005^{* *}$ & $0.0005 * *$ & $0.0001^{* *}$ & $-0.0009 * *$ \\
\hline Demography & $0.146^{* *}$ & & & & \\
\hline$\rho \_$hhm_tot & & $0.145^{* *}$ & $0.145 * *$ & $0.145^{* *}$ & $0.145^{* *}$ \\
\hline
\end{tabular}

Note: ** and * indicate significant at the $1 \%$ and $5 \%$ significance level, respectively

Source: research findings

Table 5: The QUAIDS Parameter Estimates for Indonesian urban ( $N=135,976)$.

The factors affecting animal foods demand in Indonesia

The finding of QUAIDS analysis shows the income, price, and socio-demographic factors significantly influence the demand for animal foods. Table 6 shows the expenditure elasticity of all animal foods which was positive. It means the more augmented income the more demand for animal foods.
In other words, the households di Indonesia prefer to keep consuming protein (Shibia et al., 2017). The expenditure elasticity for eggs, chicken, beef, fish, and powder milk are $0.53 \%, 1.43 \%$, $2.18 \%, 1.53 \%$, and $1.96 \%$, respectively. Eggs are inelastic and classified as normal goods. It is because it has an income elasticity of less than one (Sacli and Ozer, 2017). Beef is the most sensitive 
to changes regarding the increment income. The effect of income results in animal foods in Indonesian households getting more elastic. This means that an increase in income will increase consumption of animal protein.

Eggs are the normal goods of animal foods group not only in the city but also in the rural areas. However, beef can be categorized as the luxuries goods, because it has the income elasticity that is more than one. Also, beef has the highest elasticity which is $2.78 \%$ in rural area, and $189 \%$ in urban area (Delport et al., 2017). It is followed by milk powder by $2.29 \%$ in rural area and $1.75 \%$ in urban. While fish attain $1.69 \%$ in rural area and $1.41 \%$ in urban. Chicken obtain $1.53 \%$ in rural area and $1.35 \%$ in urban area (Delport et al., 2017; Ackah and Appleton, 2007). The number of households' members (HHsize) shows the negative and significant effect on eggs and milk. It means that the growth of HHsize of individual could reduce eggs and milk by $0.0706 \%$ and $0.0708 \%$.

\section{Marshallian and Hicksian Own-Price Elasticities (uncompensated and compensated)}

There are many previous studies investigate the estimation of demand to analyze the consumption behavior of both individuals and households. The demand system was focused on demand consumer behavior which is beneficial to arrange government policy such as the reduce poverty program (Elijah Obayelu et al., 2009; Ivanic and Martin, 2014). The elasticity shows how much does the households respond to the price or income changing (Elijah Obayelu at al., 2009). Also, the elasticity of price and income can reflect the respond of the households to the changing of animal foods price. In this case, similar previous study has been undertaken at the developing countries such as in Tanzania (Abdulai and Aubert, 2004); in Nigeria (Elijah Obayelu et al., 2009), in Vietnam (Vu and Glewwe, 2011), and in Slovakia (Cupák et al., 2015; Robles and Keefe, 2011).

\begin{tabular}{|c|c|c|c|}
\hline Animal Foods & Indonesia & Rural & Urban \\
\hline & \multicolumn{3}{|c|}{ Marshallian (uncompensated) } \\
\hline \multirow[t]{2}{*}{ Eggs } & -0.824 & -0.827 & -0.799 \\
\hline & $(0.003)$ & $(0.005)$ & $(0.005)$ \\
\hline \multirow[t]{2}{*}{ Chicken } & -1.574 & -1.587 & -1.634 \\
\hline & $(0.009)$ & $(0.011)$ & $(0.013)$ \\
\hline \multirow[t]{2}{*}{ Beef } & -2.475 & -1.884 & -3.168 \\
\hline & $(0.038)$ & $(0.040)$ & $(0.072)$ \\
\hline \multirow[t]{2}{*}{ Fish } & -2.198 & -1.849 & -2.631 \\
\hline & $(0.017)$ & $(0.022)$ & $(0.027)$ \\
\hline \multirow[t]{3}{*}{ Milk Powder } & -1.710 & -1.734 & -1.625 \\
\hline & $(0.014)$ & 0.020 & 0.021 \\
\hline & \multicolumn{3}{|c|}{ Hicksian (Compensated) } \\
\hline \multirow[t]{2}{*}{ Eggs } & -0.534 & -0.539 & -0.494 \\
\hline & $(0.003)$ & $(0.005)$ & $(0.005)$ \\
\hline \multirow[t]{2}{*}{ Chicken } & -1.193 & -1.172 & -1.290 \\
\hline & $(0.009)$ & $(0.012)$ & $(0.013)$ \\
\hline \multirow[t]{2}{*}{ Beef } & -2.418 & -1.835 & -3.103 \\
\hline & $(0.038)$ & $(0.040)$ & $(0.072)$ \\
\hline \multirow[t]{2}{*}{ Fish } & -2.123 & -1.780 & -2.552 \\
\hline & $(.017)$ & $(0.022)$ & $(0.027)$ \\
\hline \multirow[t]{2}{*}{ Milk Powder } & -1.515 & -1.556 & -1.417 \\
\hline & $(0.014)$ & $(0.020)$ & $(0.021)$ \\
\hline
\end{tabular}

Note: standart error of mean is parentheses

Source: research findings

Table 7: Own-price elasticities.

The price elasticity comprises the Marshallian price elasticity (uncompensated elasticity) and Hicksian price elasticity (compensated elasticity) depicted by Table 7. The analysis of the QUAIDS model yields all of the price elasticity is negative which is similar to the expectation. In addition, Marshallian price elasticity has a bigger impact than Hicksian price elasticity in all urban-rural areas in Indonesia. It is aligned with the previous researches (Bopape and Myers, 2007; Elijah Obayelu et al., 2009; Abdulai and Aubert, 2004; Meenakshi and Ray, 1999). According to Abdulai and Aubert (2004), Marshallian price elasticity also

\begin{tabular}{lcccc}
\hline Animal foods & Indonesia & Rural & Urban & HHsize \\
\hline Eggs & $0.531 * *$ & $0.568^{* *}$ & $0.476^{* *}$ & $-0.001 * *$ \\
Chicken & $1.437 * *$ & $1.530^{* *}$ & $1.346^{* *}$ & $0.001 * *$ \\
Beef & $2.178^{* *}$ & $2.785^{* *}$ & $1.885^{* *}$ & $0.0002 * *$ \\
Fish & $1.538^{* *}$ & $1.695 * *$ & $1.411 * *$ & $0.0001 * *$ \\
Milk powder & $1.962 * *$ & $2.291 * *$ & $1.749 * *$ & $-0.001 * *$ \\
$\mathrm{~N}$ & 291,414 & 131,975 & 112,512 & \\
\hline
\end{tabular}

Note: ** and * indicate significant at the $1 \%$ and $5 \%$ significance level, respectively

Source: research findings

Table 6: The expenditure elasticity across commodities in Indonesia-rural-urban. 
yields a bigger impact than Hicksian price elasticity in Nigeria. It is because beef, fish, milk and chicken have elastics nature, except eggs. In other words, the increasing prices can cause the reduction of beef consumption which is bigger than the changes of such price.

The expenditure (income) elasticity in the rural area is bigger than in the urban area in term of animal protein which is illustrated in Table 5. It can implicate the income policy to be more effective for households in the rural area. Meanwhile, in the urban area, price policy can be more effective to be implemented. Table 5 illustrated the elasticity of prices in the urban area which is bigger than the rural area. Therefore, direct cash funding could be more suitable to the households in the rural area. While price subsidy could be appropriated to households in the urban area.

\section{Marshallian and Hicksian Cross-price elasticities}

In Table 8 , most of the cross-price elasticity is positive. It means that there is a substitute relationship between animal foods. On the other hand, the negative effect of animal foods is because of the complementary relationship between animal foods. For example, eggs gave a complementary nature. It means that many households can consume eggs together with the other animal foods, while other animal foods protein is substitute food. Beef can be substituted with eggs, chicken, and fish. It indicates that the more increased beef price, the more households substitute it by consuming fish $(26.81 \%)$, chicken $(7.63 \%)$, or eggs $(3.03 \%)$. The increasing of income that is followed by the decreasing of milk price and the rising of chicken, fish, and eggs can decrease the consumption of beef by $5.83 \%$ (2.434772.37645). Mostly, the coefficient of the cross price elasticity of Hicksian is positive. This is aligned with the previous research of Sacli and Ozer (2017) in Turkey. According to Sacli and Ozer (2017), five groups of animal foods have a positive coefficient of the cross Hicksian elasticity coefficient. In Turkey, if the price of beef increases, households will replace the consumption of animal food with lamb, chicken and eggs which is the same as in Indonesia. It means that there are an interrelations among animal foods in Indonesia and Turkey. In this case, the growing price of beef could impact to the substitute of other animal

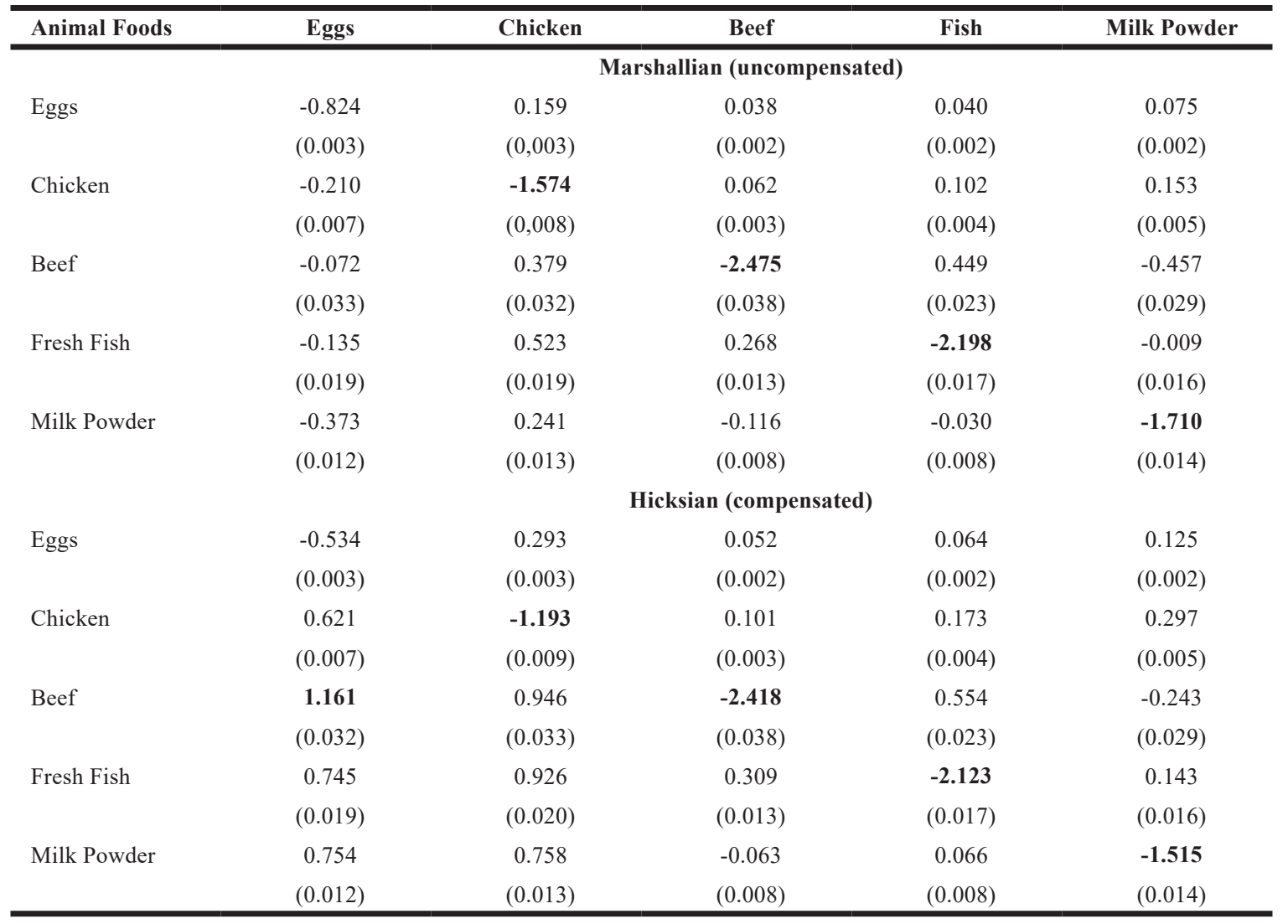

Note: Standard error of mean in parentheses

Source: research findings

Table 8: Uncompensated and Compensated cross-prices elasticities: Indonesia (All HH). 
foods that have lower price such as eggs, fish, and chicken.

The growth of beef prices is followed by increasing income. It can increase the consumption of chicken by $3.9 \%(0.06237-0.10139)$. Then, to enhance the consumption of beef in Indonesia, the government need to stabilize the price of beef. The government requires to establish the policy regarding the beef price to maintain stability and to increase the production of beef in Indonesia.

In Table 9, cross-price elasticity of animal food protein in Indonesian urban households is presented. Majority of the elasticity is positive. It means that there is a substitute relationship among animal food in the households of urban in Indonesia (Shibia at al., 2017; Angelucci and Attanasio, 2013). Cross-price elasticity of positively affect the price of eggs, chicken, and fish. It means that there is a substitute inter-relationship among beef, eggs, chicken, and fish. The increasing of beef price can be followed by the decreasing of milk price. Also, it can induce the households to shift the preference in consuming other animal foods such as eggs, chicken andfish.According to Elijah Obayelu et al. (2009), the increasing of beef price can rise the chicken consumption of the households by $3.5 \%(0.13586-0.03515)$.

In Table 10, the cross-price of elasticity of animal foods in the rural area in Indonesia is presented. The cross-price of Marshallian elasticity is higher than the cross-price of Hicksian elasticity (Elijah Obayelu et al., 2009). It is because the cross-price of Marshallian elasticity has an effect on the price and income. Meanwhile, the cross-price of Hicksian elasticity merely influences the price. Most of the cross-price elasticity of households in the urban area in Indonesia is positive. It means that among the various types of animal foods is a substitute or replace each other. The increasing price of animal protein augments the consumption of other animal foods (Delport et al., 2017; Nguyen and Winters, 2011). For example, in Indonesian urban households, rising prices for beef also increase the consumption of eggs, chicken and fish. The increase in beef prices is followed by the increasing consumption of chicken meat by $4.2 \% \quad(0.02974-0.07222)$.

\begin{tabular}{|c|c|c|c|c|c|}
\hline Animal Foods & Eggs & Chicken & Beef & Fresh Fish & Milk Powder \\
\hline & \multicolumn{5}{|c|}{ Marshallian Price Elasticity (uncompensated elasticity) } \\
\hline \multirow[t]{2}{*}{ Eggs } & -0.799 & 0.173 & 0.011 & 0.030 & 0.049 \\
\hline & $(0.005)$ & $(0.004)$ & $(0.003)$ & $(0.002)$ & $(0.003)$ \\
\hline \multirow[t]{2}{*}{ Chicken } & -0.079 & -1.634 & 0.136 & 0.136 & 0.120 \\
\hline & $(0.010)$ & $(0.013)$ & $(0.006)$ & $(0.006)$ & $(0.007)$ \\
\hline \multirow[t]{2}{*}{ Beef } & -0.801 & 0.994 & -3.168 & 0.766 & -0.259 \\
\hline & $(0.056)$ & $(0.057)$ & $(0.072)$ & $(0.041)$ & $(0.045)$ \\
\hline \multirow[t]{2}{*}{ Fresh Fish } & -0.307 & 0.661 & 0.455 & -2.631 & 0.197 \\
\hline & $(0.029)$ & $(0.031)$ & $(0.023)$ & $(0.027)$ & $(0.024)$ \\
\hline \multirow[t]{3}{*}{ Milk Powder } & -0.582 & 0.089 & -0.058 & 0.061 & -1.625 \\
\hline & $(0.018)$ & $(0.020)$ & $(0.012)$ & $(0.012)$ & $(0.021)$ \\
\hline & \multicolumn{5}{|c|}{ Hicksian Price Elasticity (compensated elasticity) } \\
\hline \multirow[t]{2}{*}{ Eggs } & -0.494 & 0.312 & 0.025 & 0.056 & 0.101 \\
\hline & $(0.005)$ & $(0.004)$ & $(0.003)$ & $(0.002)$ & $(0.003)$ \\
\hline \multirow[t]{2}{*}{ Chicken } & 0.669 & -1.290 & 0.171 & 0.200 & 0.250 \\
\hline & $(0.010)$ & $(0.013)$ & $(0.006)$ & $(0.006)$ & $(0.007)$ \\
\hline \multirow[t]{2}{*}{ Beef } & 0.598 & 1.636 & -3.103 & 0.886 & -0.017 \\
\hline & $(0.055)$ & $(0.057)$ & $(0.072)$ & $(0.041)$ & $(0.045)$ \\
\hline \multirow[t]{2}{*}{ Fresh Fish } & 0.614 & 1.084 & 0.498 & -2.552 & 0.357 \\
\hline & $(0.028)$ & $(0.031)$ & $(0.023)$ & $(0.027)$ & $(0.024)$ \\
\hline \multirow[t]{2}{*}{ Milk Powder } & 0.616 & 0.639 & -0.002 & 0.164 & -1.417 \\
\hline & $(0.017)$ & $(0.020)$ & $(0.012)$ & $(0.012)$ & $(0.021)$ \\
\hline
\end{tabular}

Note: Standard error of mean in parentheses

Source: research findings 


\begin{tabular}{|c|c|c|c|c|c|}
\hline Animal Foods & Eggs & Chicken & Beef & Fish & Milk Powder \\
\hline & \multicolumn{5}{|c|}{ Marshallian (uncompensated) } \\
\hline \multirow[t]{2}{*}{ Eggs } & -0.827 & 0.169 & 0.035 & 0.028 & 0.087 \\
\hline & $(0.005)$ & $(0.004)$ & $(0.002)$ & $(0.002)$ & $(0.003)$ \\
\hline \multirow[t]{2}{*}{ Chicken } & -0.279 & -1.587 & 0.030 & 0.095 & 0.144 \\
\hline & $(0.010)$ & $(0.011)$ & $(0.004)$ & $(0.005)$ & $(0.007)$ \\
\hline \multirow[t]{2}{*}{ Beef } & 0.090 & 0.153 & -1.884 & 0.226 & -0.414 \\
\hline & $(0.038)$ & $(0.037)$ & $(0.040)$ & $(0.026)$ & $(0.037)$ \\
\hline \multirow[t]{2}{*}{ Fish } & -0.180 & 0.530 & 0.137 & -1.849 & -0.071 \\
\hline & $(0.026)$ & $(0.026)$ & $(0.015)$ & $(0.022)$ & $(0.022)$ \\
\hline \multirow[t]{3}{*}{ Milk Powder } & -0.195 & 0.279 & -0.107 & -0.054 & -1.734 \\
\hline & $(0.017)$ & $(0.017)$ & $(0.010)$ & $(0.011)$ & $(0.020)$ \\
\hline & \multicolumn{5}{|c|}{ Hicksian (compensated) } \\
\hline \multirow[t]{2}{*}{ Eggs } & -0.539 & 0.301 & 0.048 & 0.052 & 0.137 \\
\hline & $(0.005)$ & $(0.004)$ & $(0.002)$ & $(0.002)$ & $(0.003)$ \\
\hline \multirow[t]{2}{*}{ Chicken } & 0.627 & -1.172 & 0.072 & 0.172 & 0.301 \\
\hline & $(0.009)$ & $(0.012)$ & $(0.004)$ & $(0.005)$ & (0.007) \\
\hline \multirow[t]{2}{*}{ Beef } & 1.127 & 0.629 & -1.835 & 0.314 & -0.234 \\
\hline & $(0.037)$ & $(0.037)$ & $(0.040)$ & $(0.026)$ & $(0.037)$ \\
\hline \multirow[t]{2}{*}{ Fish } & 0.632 & 0.903 & 0.175 & -1.780 & 0.070 \\
\hline & $(0.025)$ & $(0.026)$ & $(0.015)$ & $(0.022)$ & $(0.022)$ \\
\hline \multirow[t]{2}{*}{ Milk Powder } & 0.832 & 0.75 & -0.059 & 0.034 & -1.556 \\
\hline & $(0.017)$ & $(0.017)$ & $(0.010)$ & $(0.011)$ & $(0.020)$ \\
\hline
\end{tabular}

Note: Standard error of mean in parentheses

Source: research findings

Table 10: Uncompensated and Compensated cross-prices elasticities: Indonesian rural.

The growth of beef consumption is higher than the consumption in urban households. This indicates that chicken meat has a high preference in rural households.

\section{Conclusion}

This paper presents a model for animal food demands system by using 2016 Susenas data. Data analysis includes the quadratic of income to test the non-linear relationship between income and share of expenditure. The results of the QUAIDS model analysis show that all animal foods in Indonesia are elastic except eggs. It indicates that the percentage change in the amount consumed by each animal food is greater than the percentage change in price. This will emerge the huge implications in fulfilling households' protein consumption in Indonesia. To date, three provinces from 34 provinces in Indonesia consume protein in accordance with national protein sufficiency rates. Beef is the most influential to changes the prices, income, and preference. The highest demands elasticity of beef, milk, fish, chicken meat and eggs are $2.19 \% ; 1.96 \% ; 1.53 \%$; $1.43 \%$ and $0.53 \%$, respectively. The increasing beef prices are followed by the increasing of chicken meat consumption in Indonesia by $3.9 \%$. It comprises chicken meat consumption in urban areas by $3.5 \%$ and in rural areas by $4.2 \%$. The government should apply the income policy which will be more effective in rural areas. Also, the government should implement price policy which will be more effective in the urban area. The Indonesian government should develop a strategy that motivates the household to have a more diversified diet.

$\mathrm{HH}$ size also has a very significant effect on animal foods consumption. This requires a policy to improve households' food security. All animal foods have high-income elasticity except eggs. The policies related to income will encourage the increasing of beef consumption. Therefore, the encouragement of beef consumption and the stabilization of beef production by increasing income can be a more effective way. Also, the short-term targeted income transfer programs such as the short-term credit programs to the poor people can be potential to activate the households' food security which was similar to Nigerian government policy. 
This research applies the new development of AIDS models namely the QUAIDS model which is directed at finding a framework for animal food demand models in Indonesia. Throughout the review of the latest literature, such research is still rarely found in Indonesia. Mostly the QUAIDS model applied at province level by considering the region type only. This study only included five groups of animal food sources of protein, namely eggs, chicken, beef, fresh fish, and milk powder.

Theoretically, the QUAIDS model that has been applied in several studies can be combined with welfare analysis and poverty analysis. Related with welfare analysis, the concepts of compensating variation (CV), equivalent variation (EV) and consumer surplus (CS) developed by Araar and Verme (2016) will be used. In measuring the impact of price changes on poverty, the concept such as Price Elasticity of Poverty (PEP), and Price Index for the Poor (PIP) that developed by Son and Kakwani (2009) will be applied. Integration of all of these approaches will not only provide impact price changes on "animal source foods" demand and consumption behavior, but also insight how the impact price changes for the poor households relative to the non-poor households in order to generate pro-poor policy recommendation. This idea will be presented in the other articles.

\section{Acknowledgements}

This research was funded by the Ministry of Research, Technology, and Higher Education through Doctoral Dissertation Research Grant, in 2018 (No. 212/B.07/U.V/LPPM/2018). This research was an output from the first authors' dissertation in the Doctoral Program in Agricultural Sciences at Brawijaya University, Malang, Indonesia. The authors wish to thank National Bureau of Statistics that provided statistical data required in this research. Authors are thankful to all statistical team who favour the authors in analysing data.

\section{Corresponding authors}

Nikmatul Khoiriyah, Assistant Professor of Agricultural Economics

Faculty of Agriculture, University of Islam Malang, Jalan MT Haryono, 163 Malang, 65144, Indonesia

Phone: +6281234701239', Email:nikmatul@unisma.ac.id

\section{References}

[1] Abdulai, A. and Aubert, D. (2004) "A cross-section analysis of household demand for food and nutrients in Tanzania", Agricultural Economics, Vol. 31, No. 1, pp. 67-79. E-ISSN 18059295 , ISSN 0139 570X DOI 10.1111/j.1574-0862.2004.tb00222.x.

[2] Ackah, C. and Appleton, S. (2007) "Food price changes and consumer welfare in Ghana in the 1990s", No. 07/03, Credit Research Paper. [Online]. Available: http:/hdl.handle. net/10419/80310 [Accessed: 20 Nov. 2019].

[3] Agustina, T. (2016) “Outlook Susu”, Jakarta, Pusat Data dan Sistem Informasi Pertanian Sekretariat Jenderal Kementerian Pertanian.

[4] Angelucci, M. and Attanasio, O. (2013) "The demand for food of poor urban mexican households: Understanding policy impacts using structural models", American Economic Journal: Economic Policy, Vol. 5, No. 1, pp. 146-178. ISSN 19457731. DOI 10.1257/pol.5.1.146.

[5] Akaichi, F. and Revoredo-Giha, C. (2014) "The demand for dairy products in Malawi", African Journal of Agricultural and Resource Economics, Vol. 9, No 3, pp. 214-225 ISSN 1993-3738. DOI 10.22004/ag.econ.183894.

[6] Alem, Y. (2011) "The impact of food price inflation on consumer welfare in urban Ethiopia: A quadratic almost ideal demand system approach". University of Gothenburg.

[7] Araar, A. and Verme, P. (2019) "Theory and Computation", In Prices and Welfare, pp. 19-46, Palgrave Pivot, Cham. [Online]. Available: https://link.springer.com/chapter/10.1007/978-3-030-17423-1_3 [Accessed: 20 Nov. 2019]. DOI I 10.1007/978-3-030-17423-1_3.

[8] Attanasio, O., Di Maro, V., Lechene, V. and Phillips, D. (2013) "Welfare consequence of increases in food prices in rural Mexico and Colombia", Journal of Development Economics, Vol. 104, pp. 136-151. ISSN 0304-3878. DOI 10.1016/j.jdeveco.2013.03.009. 
[9] Baharumshah, A. Z. and Mohamed, Z. A. (1993) "Demand for meat in Malaysia: An application of the almost ideal demand system analysis", Pertanika Social Science and and Humanities, Vol. 1, No. 1, pp. 91-95. 1SSN 0128-7702.

[10] Banks, J., Blundell, R. and Lewbel, A. (1997) "Quadratic Engel curves and consumer demand", Review of Economics and Statistics, Vol. 79, No. 4, pp. 527-539. E-ISSN 1530-9142, ISSN 0034-6535. DOI 10.1162/003465397557015.

[11] Bopape, L. and Myers, R. (2007) "Analysis of household demand for food in South Africa: Model selection, expenditure endogeneity, and the influence of socio-demographic effects", In The African Econometrics Society Annual Conference, 2007 Citeseer, pp. 1-21.

[12] Cupák, A., Pokrivčák, J. and Rizov, M. (2015) "Food demand and consumption patterns in the new EU member states: The case of Slovakia", Ekonomický časopis, Vol. 63, No. 4, pp. 339-358. ISSN 0013-3035.

[13] Deaton, A. (1990) "Price elasticities from survey data: extensions and Indonesian results, Journal of econometrics, Vol. 44, No. 3, pp. 281-309. ISSN 0304-4076. DOI 10.1016/0304-4076(90)90060-7.

[14] Delport, M., Louw, M., Davids, T., Vermeulen, H. and Meyer, F. (2017) "Evaluating the demand for meat in South Africa: an econometric estimation of short term demand elasticities", Agrekon, Vol. 56, No. 1, pp.13-27. E-ISSN 2078-0400, ISSN 0303-1853. DOI 10.1080/03031853.2017.1286249.

[15] Elijah Obayelu, A., Okoruwa, V. O. and Ajani, O. I. Y. (2009) “Cross-sectional analysis of food demand in the North Central, Nigeria: The quadratic almost ideal demand system (QUAIDS) approach", China Agricultural Economic Review, Vol. 1, No. 2, pp. 173-193. ISSN 1756-137X. DOI 10.1108/17561370910927426.

[16] Fabiosa, J. F. (2005) "Growing demand for animal-protein-source products in Indonesia: trade implications, CARD Reports and Working Papers, No. 419. [Online]. Available: https://lib.dr.iastate.edu/card_workingpapers/419 [Accessed: 15 Dec. 2019].

[17] Muliany, H. P. (2016) "Outlook Daging Ayam 2016”, Jakarta, Pusat Data dan Sistem Informasi Pertanian Sekretariat Jenderal Kementerian Pertanian.

[18] Ivanic, M., and Martin, W. (2014) "Short-and long-run impacts of food price changes on poverty". The World Bank. DOI 10.1596/1813-9450-7011

[19] Krisnamurthi, B. (2016) "Sawit Indonesia“. Tabloid Sinar Tani.

[20] Legendre, C., Debure, C., Meaume, S., Lok, C., Golmard, J. L. and Senet, P. (2008) "Impact of protein deficiency on venous ulcer healing", Journal of Vascular Surgery, Vol. 48, No. 3, pp. 688-693. ISSN 0741-5214. DOI 10.1016/j.jvs.2008.04.012.

[21] Meenakshi, J. V. and Ray, R. (1999) "Regional differences in India's food expenditure pattern: a complete demand systems approach", Journal of International Development: The Journal of the Development Studies Association", Vol. 11, No. 1, pp. 47-74. E-ISSN 1099-1328. DOI 10.1002/(SICI)1099-1328(199901/02)11:1<47::AID-JID549>3.0.CO;2-Y.

[22] Nguyen, M. C. and Winters, P. (2011) "The impact of migration on food consumption patterns: The case of Vietnam", Food Policy, Vol. 36, No. 1, pp. 71-87. ISSN 0306-9192. DOI 10.1016/j.foodpol.2010.11.001.

[23] Pangaribowo, E. H. and Tsegai, D. W. (2011) "Food demand analysis of Indonesian households with particular attention to the poorest", Working Paper, ZEF Discussion Papers on Development Policy, No. 151, University of Bonn, Center for Development Research (ZEF), Bonn.

[24] Poi, B. P. (2012) "Easy demand-system estimation with quaids", The Stata Journal, Vol. 12, No. 3, pp. 433. ISSN 1521-8767. DOI 10.1177/1536867X1201200306. 
[25] Robles, M. and Keefe, M. (2011) "The effects of changing food prices on welfare and poverty in Guatemala ", Development in Practice, Vol. 21, No. 4-5, pp. 578-589. E-ISSN 1364-9213, ISSN 0961-4524. DOI 10.1080/09614524.2011.561293.

[26] Roch Widaningsih (2016) “Outlook Telur 2016”, Jakarta, Pusat Data dan Sistem Informasi Pertanian Sekretariat Jenderal Kementerian Pertanian.

[27] Sacli, Y. and Ozer, O. O. (2017) "Analysis of factors affecting red meat and chicken meat consumption in Turkey using an ideal demand system model", Pakistan Journal of Agricultural Sciences. Vol. 54, No. 4, pp. 933-942. ISSN 0552-9034. DOI 10.21162/PAKJAS/17.5849.

[28] Shibia, M., Rahman, S. and Chidmi, B. (2017) "Consumer demand for meat in Kenya: an examination of the linear approximate almost ideal demand system", In Southern Agricultural Economics Association (SAEA) Annual Meetings in Mobile, Conference Paper, pp. 1-19. DOI 10.22004/ag.econ.252789.

[29] Statistik, B. P. (2015) "Produksi Daging, Kulit, Susu dan Telur Menurut Jenis Ternak Dan Unggas Tahun 2011-2014". [Online]. Available: https://www.bps.go.id/subject/24/peternakan. html\#subjekViewTab3 [Accessed: 20 Feb. 2019].

[30] Son, H. H.and Kakwani, N. (2009) "Measuring the impact of price changes on poverty", The Journal of Economic Inequality, Vol. 7, No. 4, No. of Art. 395. E-ISSN 1573-8701, ISSN 1569-1721. DOI 10.1007/s10888-008-9093-0.

[31] Suryani, R. (2016) “Outlook Daging Sapi 2016”, Jakarta, Pusat Data dan Sistem Informasi Pertanian Sekretariat Jenderal Kementerian Pertanian.

[32] Tefera, N. , Demeke, M., Rashid, S. and Kayitakire, F. (2014) "A Dynamic analysis of food demand patterns and habit effects: panel evidence from rural households in Ethiopia", Conference: Information For Meeting African's Transformation And Food Security Goals -IMAAFS; Addis Ababa, 1-3 Oct. 2014.

[33] Uregia, N. T., Desta, M. D. and Rashid, S. (2012) "Welfare impacts of rising food prices in rural Ethiopia: a Quadratic almost ideal demand srstem approach", In International Association of Agricultural Economists (IAAE) Triennial Conference, 2012, pp. 1-47.

[34] Vu, L. and Glewwe, P. (2011) "Impacts of rising food prices on poverty and welfare in Vietnam", Journal of Agricultural and Resource Economics. Vol. 36, No. 1, pp. 14-27. E-ISSN 2327-8285, ISSN 1068-5502. 